\title{
Toward a Heterodox Approach: Reconciling Stabilization and Economic Growth in Pakistan
}

\author{
Irfan ul Haque* and Sahar Amjad**
}

\begin{abstract}
This article attempts to show that a strategy for accelerated growth for Pakistan is both necessary and feasible. Pakistan's macroeconomic conditions are broadly similar to some of its more rapidly growing neighbors. The country's macroeconomic imbalances and inflation need to be brought down, but the required adjustment does not entail precipitate action, which could further depress the economy. We develop a "Heterodox Scenario," which shows that macroeconomic adjustments can be phased in over the next few years and will be easier to make if the economy were to grow more rapidly. For accelerated growth to materialize, as a minimum, determined steps are needed to overcome the energy crisis, sharply raise the investment rate - particularly, private investment - and strengthen Pakistan's competitiveness in the world market. A national strategy is needed toward that end.
\end{abstract}

Keywords: Growth, inflation, economy, strategy, Pakistan.

JEL classification: O10, E22.

\section{Introduction}

With continuing political turmoil, rising violence, serious law and order failures, and frequent and prolonged power cuts, the state of Pakistan's economy could hardly be other than parlous. That in these circumstances the country's economic performance can improve and the economy embark on a trajectory of rapid growth can not be taken as a serious proposition. Investment, key to economic growth, requires a stable, predictable, and secure economic environment. Conventional economic wisdom holds that economic — and political—stability precede accelerated economic growth. Thus, before exploring possibilities for economic growth, a measure of economic stability must be achieved and macroeconomic imbalances must be restored to sustainable levels.

\footnotetext{
${ }_{* *}^{*}$ Special Advisor, Financing for Development, South Centre, Geneva.

** Teaching and Research Fellow, Lahore School of Economics.
} 
But economic instability is a relative, not an absolute, metric. It can relate to fluctuations in output, employment, or prices; though, in the context of developing countries, rising prices and inflationary expectations are the usual concerns of the stabilization programs. Experience, however, shows that, while economic growth under high and accelerating inflation is difficult to sustain, price stability in the absence of adequate economic growth remains an elusive goal when fiscal retrenchment and other contractionary measures take their toll on society. Pakistan's own experience stands testimony to this.

This dilemma gives rise to a number of questions. Is there a tolerable level of price instability for a country? Is there an inflationgrowth link? Is inflation inimical to investment and economic growth? Do stabilization measures help or hinder output growth? Is high economic growth compatible with stability? This article attempts to answer these questions with the Pakistani economy in view.

The next section explores the relationship between inflation and economic growth and discusses whether individual countries have a certain optimal inflation level that is conducive to output growth. This is followed by a review, in Section 3, of Pakistan's key macroeconomic indicators in comparison to four high-growth economies in its neighborhood-Bangladesh, India, Indonesia, and Sri Lanka. This discussion examines whether Pakistan's macroeconomic performance is significantly different from that of the other economies. If it is broadly similar, then the country's low growth rate could be due to factors other than inflation and macroeconomic imbalances.

In Section 4, we develop a simple macroeconomic accounting framework where economic growth is made an explicit policy target, which is in contrast to the traditional International Monetary Fund (IMF) stabilization programs that treat it as an outcome. This exercise is an attempt to show that it should be feasible for Pakistan to attain accelerated growth even with the existing high inflation and fiscal deficit. More significantly, we see that accelerated economic growth could actually help improve stability. The question of how Pakistan's economic growth may actually be accelerated and sustained is taken up in Section 5. The final section offers a few concluding remarks. 


\section{The Inflation-Economic Growth Link}

The inflation-growth link is far from straightforward. One reason for the ambiguity is that price rises are normally associated with constrained supply, which economic growth should relieve, thus easing price pressures. The direction of causation is another reason for confusion, i.e., whether the impact of output growth on inflation or its opposite is the concern of policymakers. In advanced countries, monetary policy tends to target the build-up of inflationary pressures as unemployment falls. This phenomenon of inflation accelerating as unemployment declines is captured in the so-called Phillips curve, which, in its different mutations, continues to define policy in advanced countries.

In the context of developing countries, however, inflation is deemed to hinder economic growth, but the exact relationship is unclear. The actual experience of developing countries shows great diversity with respect to the inflation-growth linkage. Table 1 gives data on inflation and economic growth for the world's different regions as well as a few key countries, which indicates wide variations across countries and time periods.

Table 1: GDP growth and inflation (1965-2010)

\begin{tabular}{lccccccccc} 
& \multicolumn{1}{c}{ (I) } & & \multicolumn{4}{c}{ (II) } \\
& \multicolumn{3}{c}{ GDP growth } & & \multicolumn{3}{c}{ (Percentage) } \\
\cline { 2 - 10 } & $\mathbf{1 9 6 5 -}$ & $\mathbf{1 9 8 0 -}$ & $\mathbf{1 9 9 0 -}$ & $\mathbf{2 0 0 0 -}$ & $\mathbf{1 9 6 5 -}$ & $\mathbf{1 9 8 0 -}$ & $\mathbf{1 9 9 0 -}$ & $\mathbf{2 0 0 0 -}$ \\
\multicolumn{1}{c}{ Region/country } & $\mathbf{8 0}$ & $\mathbf{9 0}$ & $\mathbf{2 0 0 0}$ & $\mathbf{1 0}$ & $\mathbf{8 0}$ & $\mathbf{9 0}$ & $\mathbf{2 0 0 0}$ & $\mathbf{1 0}$ \\
\hline Sub-Saharan Africa & 4.20 & 2.10 & 2.32 & 4.80 & 11.40 & 20.00 & 9.01 & 7.03 \\
East Asia/Pacific & 7.30 & 7.80 & 3.07 & 3.70 & 9.30 & 6.00 & 3.74 & 3.43 \\
Korea, Rep. of & 9.90 & 9.70 & 6.19 & 4.16 & 18.40 & 5.10 & 6.03 & 2.63 \\
South Asia & 3.60 & 5.20 & 5.21 & 7.12 & 8.30 & 8.00 & 8.10 & 6.24 \\
Middle East/ & 6.70 & 0.50 & 4.10 & 4.30 & 13.60 & 7.50 & 5.85 & 6.68 \\
North Africa & & & & & & & & \\
Latin America/ & 6.00 & 1.60 & 3.24 & 3.37 & 31.80 & 192.1 .0 & 8.08 & 5.68 \\
Caribbean & & & & & & & & \\
OECD & 3.70 & 3.10 & 2.63 & 1.50 & 7.60 & 4.20 & 3.34 & 2.57 \\
Japan & 6.40 & 4.10 & 1.19 & 0.75 & 7.70 & 1.50 & 0.11 & -1.20 \\
China & 6.67 & 9.35 & 10.45 & 10.5 & 0.26 & 5.45 & 7.24 & 4.13 \\
India & 3.58 & 5.57 & 5.48 & 7.69 & 7.97 & 8.61 & 8.09 & 6.02 \\
\hline
\end{tabular}

Source: World Bank (2012). 
Japan and Korea, for example, grew rapidly during 1965-80, but also had above-average inflation for that period. The same was true of the Middle Eastern and North African economies. China, on the other hand, had very low inflation but also relatively high economic growth during that period. In subsequent periods, however, Chinese growth accelerated but so did inflation, though remaining moderate by developing-country standards. Latin America had a record of high inflation but economic growth remained generally lower than that of other developing countries. The South Asian experience shows that, as growth accelerated from the lows of the 1965-80 period, inflation generally declined.

Econometric studies of the inflation-growth link have also produced mixed results. Relying on a sample of 101 countries covering the period 1960-89, Fischer (1993) finds a negative relationship between high inflation and output growth, and attributes it to a lowering of investment and productivity growth. Dornbusch and Fisher (1993) show that inflation below 20 percent could be maintained for long periods without serious macroeconomic consequences. The study observes that, during their period of rapid growth, the East Asian economies maintained inflation well within this limit, which would today be considered too high. On the other hand, Bruno and Easterly (1996) note that inflation had little impact on growth at rates below 40 percent.

Pakistan's own experience also suggests no clear link between stability and growth. The scatter diagram in Figure 1, covering data for 1990-2010, shows years of high growth but low inflation; low growth with low inflation; and, in one instance (2009), low growth and very high inflation (over 20 percent). Overall, output growth fluctuated in the range of 2 to 8 percent, while inflation showed stickiness within a band of 8-12 per cent. ${ }^{1}$

\footnotetext{
${ }^{1}$ Thirteen of the 21 observations fell in this range.
} 
Figure 1: Inflation-growth relationship for Pakistan

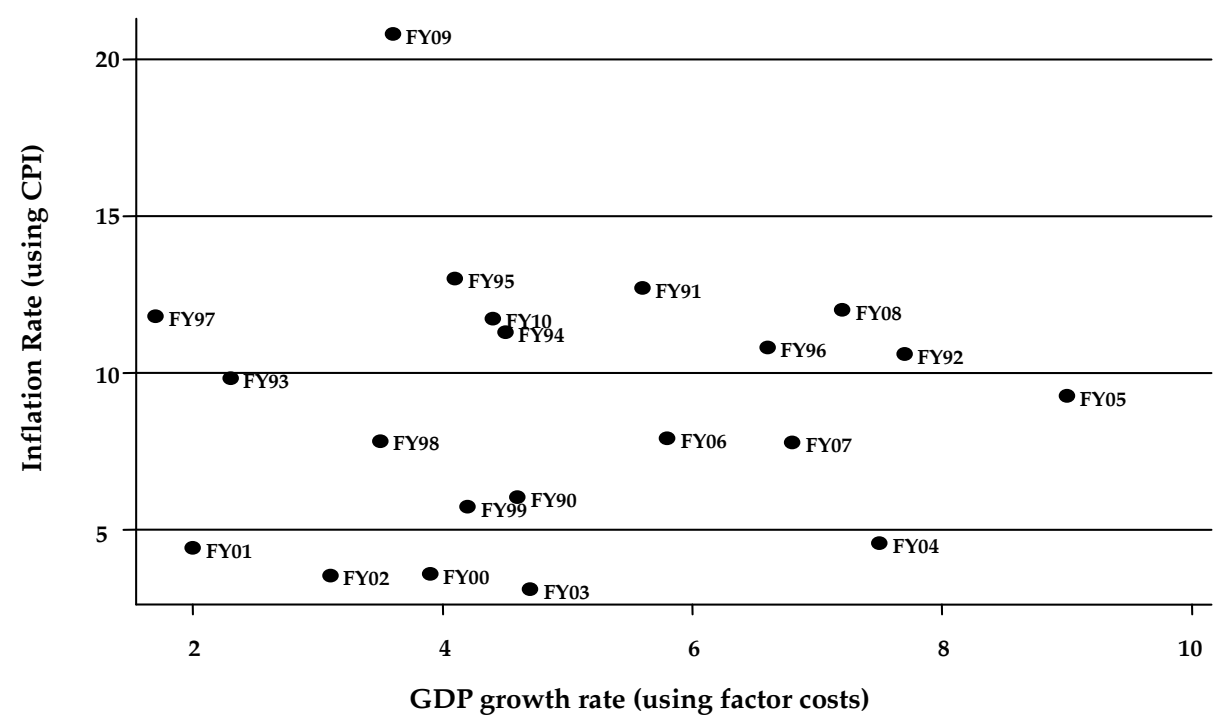

In brief, the relationship between inflation and growth is not stable or smooth. While a certain level of inflation helps to grease the economic wheels, beyond a certain point, it begins to hamper investment and productivity growth. The reason is that, at low inflation, relative prices are quite stable and investor and consumer decisions remain, by and large, unaffected. But high and accelerating inflation creates an altogether different situation. Here price adjustments occur at an accelerating pace, resulting in the breakdown of established wage-price contracts and other indexing mechanisms. This causes unpredictable shifts in relative prices and increases overall uncertainty. High inflation, if unchecked, also tends to accelerate and spiral out of control.

The innate dynamics of high- and low-inflationary situations are, therefore, distinctly different (Haque, 1995). In high-inflation situations, what the government might or might not do adds to uncertainty. Because nominal interest rates tend to be sticky, high inflation can turn real interest rates negative and more volatile. This has an impact on savings and investment decisions. Exchange rate management also becomes more difficult and unpredictable: Prompt adjustments of the rate are liable to feed inflation, while delays foment speculation and hurt industries exposed to foreign trade. Balance of payments difficulties typically accompany high inflation because the trade balance worsens as the fiscal deficit rises. Financing of either deficit through foreign borrowing becomes increasingly difficult and costly as lenders become wary of the deteriorating 
macroeconomic situation. Economies that are heavily dependent on foreign direct investment or on foreign trade are therefore more vulnerable to capital flight and the loss of competitiveness caused by high inflation. Thus, the relative openness of an economy is another factor determining how inflation affects output growth.

In short, while the evidence on the inflation-growth link is conflicting, it does show that inflation beyond a certain point begins to hurt economic growth. In other words, the inflation-growth relationship is characterized by a "kink", i.e., inflation's impact on output growth is inconsequential or could actually be favorable at low rates, but becomes progressively adverse as it accelerates. On the basis of a sample of 165 countries, Espinoza, Leon, and Prasad (2010) estimate that developing economies have an inflation threshold (the point at which the kink appears) of between 7 and 13 percent, but that inflation above 10 percent begins to hurt growth. The threshold for advanced countries is found to be much lower (below 3 percent). For Pakistan during 1973-2000, Mubarik (2005) finds that inflation below 5 percent can be favorable to economic growth, but that if it exceeds the estimated threshold rate of 9 percent, economic growth starts to suffer.

\section{Pakistan vs. its Regional Neighbors}

Bringing down fiscal deficits and controlling inflation have remained recurrent goals of macroeconomic policy in Pakistan. Over the last two decades, the country entered into eight IMF programs (all but two during the 1990s) - involving stabilizing policies and structural economic reform-but none was taken to completion. Apart from expenditure cuts, the reforms sought to address structural weaknesses, i.e., strengthening tax administration, widening the tax net, and privatizing loss-making stateowned enterprises. The intention was to reduce the government's reliance on monetary expansion through improved public finances while stimulating private investment and productivity growth. Whether or not the measures were adequate, Pakistan's economy was remarkably unaffected. If the periods of rapid growth (2004-07) and high inflation (2008-10) are excluded, output growth remained stubbornly at around 4 percent while inflation stayed at over 8 percent.

This failure of policy gives a very bleak picture of Pakistan's ability to overcome its problems. However, a comparison of key macroeconomic data with other countries in the region suggests that, while Pakistan's problems are serious and call for bold and concerted action, its economic 
management, while by no means ideal, has not been entirely hopeless. In terms of various macroeconomic indicators, Pakistan is broadly similar to the region's other countries-Bangladesh, India, Indonesia, and Sri Lanka-even as its average growth rate of less than 5 percent is the lowest and average inflation highest. India's growth rate, in contrast, averaged above 8 percent during 2005-10, while growth in the other three economies averaged 6 percent (see Table 2). Because of the sharp downturn in economic activity following the 2008 economic crisis, Pakistan's growth appears also to be much more volatile. The coefficient of variation of growth for Pakistan was 45 percent; while it was about half that magnitude for India and Sri Lanka and much lower for Indonesia and Bangladesh.

Table 2: GDP growth rates (2005-10)

\begin{tabular}{lcccccccc}
\hline Country & $\mathbf{2 0 0 5}$ & $\mathbf{2 0 0 6}$ & $\mathbf{2 0 0 7}$ & $\mathbf{2 0 0 8}$ & $\mathbf{2 0 0 9}$ & $\mathbf{2 0 1 0}$ & Average & $\begin{array}{c}\text { Coefficient } \\
\text { of variation }\end{array}$ \\
\hline Bangladesh & 6.0 & 6.6 & 6.4 & 6.2 & 5.7 & 6.1 & 6.2 & 5.1 \\
India & 9.4 & 9.7 & 9.8 & 4.9 & 9.1 & 8.8 & 8.6 & 21.6 \\
Indonesia & 5.7 & 5.5 & 6.3 & 6.0 & 4.6 & 6.1 & 5.7 & 10.7 \\
Pakistan & 7.7 & 6.2 & 5.7 & 1.6 & 3.6 & 4.1 & 4.8 & 44.9 \\
Sri Lanka & 6.2 & 7.7 & 6.8 & 6.0 & 3.5 & 8.0 & 6.4 & 25.3 \\
\hline
\end{tabular}

Source: World Bank (2012).

Table 3 contains key fiscal performance indicators for Pakistan and its neighboring economies. These indicators are: central government debt, tax revenue, and the public deficit, all given as percentages of GDP. While the public debt ratio in Indonesia is considerably lower (an average of 37 percent) and Sri Lanka's much higher (88 percent), Pakistan's public debt ratio is virtually the same as that of India, if anything, lower. (Data for Bangladesh is not available.) 
Table 3: Fiscal performance indicators

\begin{tabular}{|c|c|c|c|c|c|c|c|}
\hline \multirow{2}{*}{ Indicator/country } & \multirow[b]{2}{*}{2005} & \multirow[b]{2}{*}{2006} & \multirow[b]{2}{*}{2007} & \multirow[b]{2}{*}{2008} & \multicolumn{3}{|c|}{ (Percentage of GDP) } \\
\hline & & & & & 2009 & 2010 & Average \\
\hline \multicolumn{8}{|l|}{ Central govt. Debt } \\
\hline India & 61.2 & 59.1 & 56.5 & 56.6 & 53.7 & 46.1 & 55.53 \\
\hline Indonesia & 47.3 & 39.0 & 35.2 & 33.1 & 28.4 & 26.1 & 34.84 \\
\hline Pakistan & 55.8 & 54.1 & 57.9 & 54.6 & 52.4 & - & 55.00 \\
\hline Sri Lanka & 90.6 & 88.7 & 85.0 & - & - & - & 88.10 \\
\hline \multicolumn{8}{|l|}{ Tax revenue } \\
\hline Bangladesh & 8.2 & 8.2 & 8.1 & 8.8 & 8.6 & - & 8.4 \\
\hline India & 9.9 & 11.0 & 11.9 & 10.8 & 9.7 & 9.5 & 10.5 \\
\hline Indonesia & 12.5 & 12.3 & 12.4 & 13.0 & 11.4 & 10.9 & 12.1 \\
\hline Pakistan & 9.6 & 9.4 & 9.8 & 9.9 & 9.3 & 10.0 & 9.7 \\
\hline Sri Lanka & 13.7 & 14.6 & 14.2 & 13.3 & - & - & 14.0 \\
\hline \multicolumn{8}{|l|}{ Public deficit } \\
\hline Bangladesh & -1.1 & -1.4 & -1.3 & -1.0 & -1.7 & - & -1.3 \\
\hline India & -3.2 & -2.2 & -0.5 & -4.9 & -5.1 & -3.7 & -3.3 \\
\hline Indonesia & -0.1 & -0.6 & -1.0 & -0.3 & -1.7 & -0.6 & -0.7 \\
\hline Pakistan & -3.2 & -4.2 & -4.2 & -7.4 & -4.8 & -5.0 & -4.8 \\
\hline Sri Lanka & -7.0 & -6.9 & -6.5 & -6.6 & - & - & -6.7 \\
\hline \multicolumn{8}{|c|}{ CPIA* rating: Fiscal policy } \\
\hline Bangladesh & 3.5 & 3.5 & 3.5 & 4.0 & 4.0 & 4.0 & 3.8 \\
\hline India & 3.0 & 3.5 & 3.5 & 3.5 & 3.5 & 3.5 & 3.4 \\
\hline Pakistan & 3.5 & 3.5 & 3.5 & 2.5 & 3.0 & 2.5 & 3.1 \\
\hline Sri Lanka & 3.0 & 3.0 & 3.0 & 3.0 & 3.0 & 3.0 & 3.0 \\
\hline \multicolumn{8}{|c|}{ CPIA* rating: Budgetary and financial management } \\
\hline Bangladesh & 3.0 & 3.0 & 3.0 & 3.0 & 3.0 & 3.0 & 3.0 \\
\hline India & 4.0 & 4.0 & 4.0 & 4.0 & 4.0 & 3.5 & 3.9 \\
\hline Pakistan & 3.5 & 3.5 & 3.5 & 3.5 & 3.5 & 3.5 & 3.5 \\
\hline Sri Lanka & 4.0 & 4.0 & 4.0 & 4.0 & 4.0 & 4.0 & 4.0 \\
\hline
\end{tabular}

* CPIA stands for "Country Policy International Assessment" undertaken periodically by the World Bank. The ranking is from 1 to 5 .

Source: World Bank (2012).

Pakistan's revenue raising performance is generally regarded as abysmal but, in fact, it is broadly similar to that of other countries. At 9.7 percent of GDP, Pakistan's revenue collection is better than that of 
Bangladesh and only a little inferior to that of India (10.5 percent). In contrast, Sri Lanka-the top performer in this group-manages to raise some 14 percent of GDP in revenue, which is still not a particularly outstanding achievement. Indonesia's performance, at 12 percent, falls somewhere in the middle.

As part of its monitoring of economic performance, the World Bank ranks countries according to the quality of fiscal policy and budgetary and financial management; this ranking is known as the Country Policy International Assessment or CPIA and is also reported in Table 3. With respect to fiscal policy, Bangladesh emerges as the top performer (with a ranking of 3.8 out of 5) but as the poorest performer in terms of budgetary and financial management. The opposite is the case for Sri Lanka, with a ranking of 3 and 4, respectively. The ranking appears to correspond closely to the two countries' size of budget deficit (the first measure) and ability to raise revenue (the second measure). However, Pakistan's ranking-at 3.1 and 3.5 for the two measures-is only slightly below that of India, whose average ranking is, respectively, 3.4 and 3.9.

Although Pakistan's overall fiscal performance is roughly in line with the region's most rapidly growing economies, there are grounds for concern. Fiscal laxity was reported to have increased in recent monthsperhaps the abandonment of the IMF standby program was a factor-and the budget deficit for the fiscal year (FY) 2012 was expected to rise above 6 percent of GDP. ${ }^{2}$ Reduction of the deficit is obviously a key policy concern but, despite official pronouncements, no significant improvement has occurred. The fact that economic growth has been meager has not helped the fiscal situation. With respect to public expenditures, the authorities do not have much room for maneuver. Further cuts in development expenditures-which have borne the brunt of earlier cuts-are likely to hamper future growth and disproportionately hurt the poor.

Pakistan's external balance paralleled the fiscal situation. Taking the period average (2005-10), the current account deficit was 4.5 percent of GDP, only slightly worse than Sri Lanka's 4.2 percent (see Table 4). On the other hand, Bangladesh and Indonesia enjoyed a surplus of about 1.5 percent, while India's current account deficit averaged below 2 percent. While other countries' external balances were relatively stable, Pakistan's current account

\footnotetext{
${ }^{2}$ This article was prepared before the end of FY2012 and before the budgetary data for the year became available. We believe that the actual numbers would not alter the basic picture of the macroeconomy.
} 
deficit displayed wide fluctuations, from the low of 0.8 percent in 2010 to the high of 9.6 percent in 2008, the year of the economic crisis. However, leaving aside the crisis borrowing from the IMF in late 2008, the country has not, so far, experienced serious external financing difficulties.

Pakistan's savings-investment balance-the domestic counterpart of the external account-provides a sharper contrast with other countries' performance. At 18 percent, its investment rate was the lowest in the group, compared to over 30 percent for India and Indonesia and about 25 percent for Bangladesh and Sri Lanka (Table 4). Even during Pakistan's boom years of 2005-07, investment did not rise much above 20 percent of GDP. The country's savings performance is even more pitiful. While India and Indonesia save virtually one third of their output, Pakistan manages to save only 13 percent. Bangladesh (17 percent) and Sri Lanka (16 percent) cannot be considered high savers, but they too do considerably better than Pakistan.

Table 4: Key macroeconomic indicators

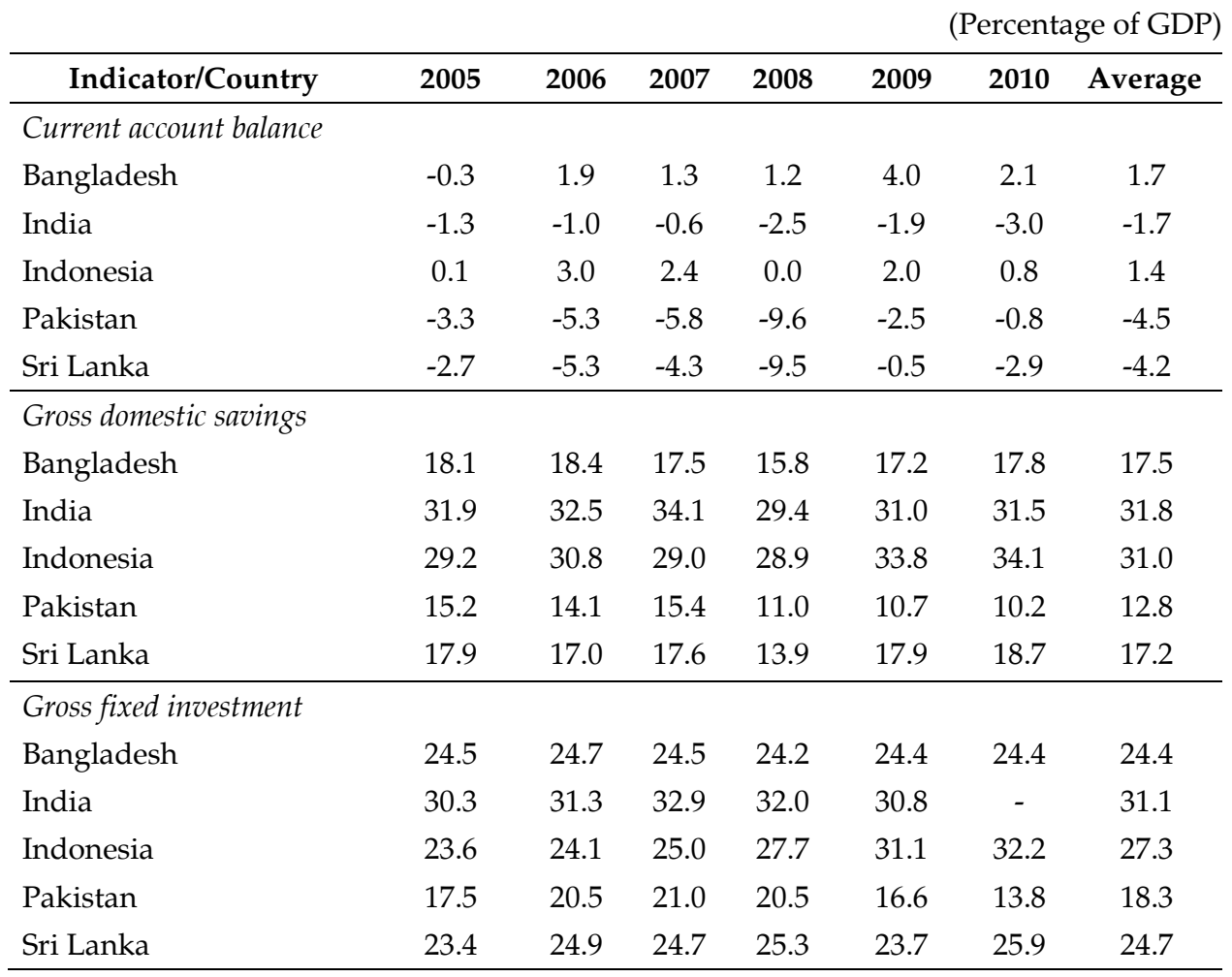

Source: World Bank (2012). 
In brief, Pakistan's overall macroeconomic performance over the past several years has been quite mixed. The fiscal deficit and negative current account cannot obviously continue at current levels and must be brought down to sustainable levels. Although domestic public debt is not, at present, unsustainably high, it could become a problem if the fiscal deficit does not come down. Inflation is running high though it does not appear to be accelerating. Similarly, the balance of payments is a vulnerable point, though the current account deficit continues to be financed by the inflow of workers' remittances and other foreign transfers. Thanks to the debt rescheduling agreements of the last decade, the debt burden is not yet onerous, but the situation could change if external borrowing becomes large. Pakistan's foreign exchange reserves at present are barely adequate, and not enough to meet unexpected adverse balance of payments developments.

These considerations indicate that Pakistan's macroeconomy needs to improve significantly and that corrective measures must be pursued vigorously and without delay. But gradual and sustained reforms in public finances are likely to be more effective and credible than a "big bang" approach, for which neither the government nor the country seem to be prepared, leaving aside the question if it would work.

\section{Stabilization through Economic Growth}

Pakistan's economy is currently operating at well below its potential; continuing with contractionary macroeconomic policies is likely to keep the economy depressed without significantly lowering inflation. Recent stabilization measures have failed to bring down inflation while economic growth has collapsed as a consequence of the public expenditure squeeze, restrictive credit policy, and increased uncertainty and worry in the private sector about the government's policy stance. The power sector crisis has further added to the problem.

Amjad, Din, and Qayyum (2011) initiated a discussion on how Pakistan's economy could break out of its current stagflationary state. At around the same time, the Planning Commission's Framework for economic growth (Pakistan, Planning Commission, 2011) was published, with a rather similar theme. It offers a range of ideas on how Pakistan's economic growth could be accelerated with macroeconomic stability:

Accelerating the economic growth rate and sustaining it at a high rate must $\ldots$ be treated as a national priority. And this 
must be achieved when resources are scarce as the country deals with a severe fiscal problem! The old paradigm of project- and government-led growth has to change. This reasoning has led the Planning Commission towards rethinking the traditional growth narrative in Pakistan (p. 3).

The call for "rethinking" entails, among other things, a critical reexamination of the conventional stabilization programs that have underpinned macroeconomic policy in Pakistan, but this the Framework fails to do so. Nevertheless, we attempt to propose an alternative to the conventional remedies. This is what the heterodox approach is about.

The essence of heterodoxy is pragmatism, i.e., policies are framed within a country context, rather than following a prescriptive boilerplate. This approach is associated with the 1980s' experiments with direct government interventions (notably, price controls) in a few Latin American countries, though its history is much older. In fact, after the Second World War, Japan was the earliest case where economic policy was targeted at a quick rehabilitation and restoration of economic growth. Significantly, the embrace of pragmatism against economic orthodoxy had the approval of the United States, the occupying power. A more recent example of heterodoxy is that of the East Asian economies-notably Korea and Malaysia-coping with the financial crisis of the late 1990s, when the IMF's prescription of severely restrictive macroeconomic policy was abandoned in favor of measures to restore growth quickly.

\subsection{The IMF's Financial Programming Framework}

Despite advances in macroeconomic theory over the years, the IMF's financial programming framework-the so-called "Polak model" has not fundamentally changed since the 1950s, and it continues to serve as the central pillar of macroeconomic policymaking. This framework consists essentially of four equations or definitional identities (Polak, 1997):

1. A change in money demand is proportional to the change in money income, implying that the (marginal) velocity of money circulation is a constant.

2. Imports are a fixed proportion of the country's income.

3. A change in money supply is equal to the change in the country's foreign exchange reserves (in local currency equivalent) plus the change in domestic credit of the country's banking system. 
4. A change in the country's foreign exchange reserves is equal to the trade balance (i.e., the difference between exports and imports) and net foreign transfers.

The logic of the model is as follows: The basic aim of the stabilization programs is to keep a country's balance of payments stable and manageable by building up foreign exchange reserves to a "safe" level, depending on the country's circumstances. With exports, foreign financing, and the buildup of reserves determined exogenously, the level of imports that the country can acquire is essentially a residual. Because imports are held to bear a fixed ratio to money income, this determines the level of money income consistent with the required buildup of foreign exchange reserves. Polak (1997) sums up the IMF conditionality thus:

The standard conditionality of the Fund thus evolved toward the inclusion of a double monetary prescription: a ceiling on the expansion of domestic assets of the central bank to achieve an acceptable balance of payments result (flow) and a floor under its holdings of net foreign assets to bring about a satisfactory (stock) reserve outcome and, at the same time, make sure that the central bank would not use excessive intervention to counter market pressures toward a more depreciated exchange rate (p. 11).

The model actually targets the key variable that the country's authorities are expected to control, that is, domestic credit. With the required change in foreign exchange reserves specified, it is basically domestic credit expansion that determines the increase in money supply. Since the IMF is averse to "crowding out" the private sector, the restraint on credit creation applies primarily to the public sector, though tightening monetary policy and other contractionary measures obviously impinge on private consumption and investment. The permissible level of public sector borrowing, thus derived, provides the magnitude of the required fiscal adjustment. How this adjustment is made is left more or less to the national authorities though the IMF is quite explicit in its preferences.

Since the velocity of money is held to be stable, the specified increase in money supply yields also the increase in money income. What the basic IMF model does not provide, however, is how the money income is split between the increase in general prices and the increase in output. The two are in effect left "dangling as quasi-exogenous variables in the Fund's operational model in its projecting mode." (Polak, 1997, p. 8). Here 
lies the model's Achilles' heel: The model does not explain the adjustment process itself, i.e., how much and how quickly stability would be achieved through the prescribed fiscal adjustment and credit squeeze. In practice, the distribution of adjustment between a decline in inflation and a change (often a decline) in output is ultimately a staff judgment (or guesstimate). Thus, the projections of the key variables are not really derived by solving a set of equations but are the result of an iterative process of reconciling different constraints. There is nothing fundamentally wrong with this process, except that it does render the projections underpinning the prescribed macroeconomic policy of questionable merit. ${ }^{3}$

The deficiency in the IMF's basic framework with respect to output growth was, however, remedied by the introduction of the concept of "structural reforms," which became a standard accompaniment to stabilization programs. These reforms typically relate to price and trade liberalization, labor market deregulation, the privatization of public enterprises, and general easing of controls and regulations in other economic spheres. These elements of policy are obviously difficult to "model"meaning their consequences are hard to measure-but they are vigorously advocated because of their expected contribution to economic growth.

\subsection{A Heterodox Alternative}

It is, however, possible to conceive of an alternative to the standard IMF model, which relies on just one modification. Output growth and inflation-instead of being left "dangling" in the system-could be adopted as explicitly specified targets to reach. Thus, given money income (the product of price and output) and the velocity of money (derived from the past data) yields, on one side, the demand for money and, on the other, the required import level. (As in the IMF framework, imports are held as a constant proportion of money income.) With the level of imports thus determined, the optimal level of foreign exchange reserves (in terms of the number of months of imports) can also be derived. With imports, exports, and the buildup of foreign exchange reserves specified, required foreign transfers are treated as the residual in the balance of payments and are

\footnotetext{
${ }^{3}$ The situation is rather different when macroeconomic imbalances arise out of overheating, i.e., when the economy is operating at full capacity with full employment. This was usually the case in advanced countries under the original Bretton Woods system of fixed exchange rates with countries committed to full employment. In such situations, there is no alternative to contractionary policies to bring about the needed macroeconomic adjustment. On the other hand, economic or financial crises in developing countries usually occur on account of external shocks (external debt, commodity prices) even while operating at well below their potential.
} 
therefore endogenous. In the IMF model, they are exogenous. On the domestic front, the demand for money yields the permissible level of domestic credit creation, given the level of foreign exchange reserves. In other words, domestic credit creation is still a policy variable, as in the IMF programming framework.

The rationale for treating output growth as a policy target in Pakistan's context rests on the following stylized facts.

1. Although the fiscal deficit needs to be reduced for longer-term macroeconomic viability, its current level does not threaten to accelerate inflation. Other economies in the region that are growing more rapidly have fiscal deficits (relative to GDP) not too different from Pakistan's.

2. Inflation is currently running high but it should be possible to bring it down gradually through output growth. An attempt to drastically reduce inflation by discouraging investment and dampening growth could turn a bad situation worse.

3. Trade and current account deficits are high but do not appear to pose, at least for the present, serious financing difficulties. Foreign exchange reserves should, ideally, be higher but are currently adequate for dealing with "normal" trade fluctuations.

4. Both foreign debt and domestic public debt need to be carefully watched but can be expected to remain manageable so long as Pakistan's economy does not take a sharp turn for the worse (IMF, 2012).

5. Pakistan's financial sector remains, on the whole, sound and healthy. Although nonperforming loans have risen for some banks and the recent large increase in the holdings of government securities in bank portfolios carries its own risks, the system-wide capital ratios are deemed adequate (IMF, 2012). This suggests that the risk of a serious banking crisis is on the low side, though the situation could change if the macroeconomy were to further deteriorate.

These stylized facts suggest that the acceleration of Pakistan's growth rate could be accompanied by improvements in the country's macroeconomic balances, and that the economy might break into a virtuous circle of economic growth and stability. At any rate, given the current situation, a drastic move toward macroeconomic tightening might do more harm than good. 
Domestic demand has not been a constraint to economic expansion in Pakistan, which suggests that demand stimulus policies would not be required for the economy to reach its potential. There are, of course, risks in opting for a high-growth route, but those should remain manageable, provided the country's external debt burden remains moderate and the banking system by and large stress-free-the two most common sources of financial crises. This diagnostic suggests that macroeconomic adjustment and stabilization could be phased in over a period of time, while conditions are laid for accelerated growth.

\subsection{Growth Scenarios}

The latest IMF's projections for Pakistan's economy are provided in the staff report on the 2011 Article IV consultations (see IMF, 2012). These projections are a useful starting point for sketching out a macroeconomic scenario that incorporates accelerated growth. The IMF scenarios are derived from its own analytical framework and discussions with the national authorities. It would, therefore, be easier to see where and why the alternative Heterodox Scenario differs from the official projections.

The IMF's projections of the key macroeconomic variables covering the period up to FY2016 are summarized in Table 5, while the results of our exercise are given in Table 6. The IMF offers two scenarios. The Baseline Scenario traces the evolution of Pakistan's economy during FY2013-FY2016, given current trends. Under this scenario, output growth does not rise above 3.5 percent, while inflation persists and slowly accelerates from the current level of 12 percent to 14 percent in FY2016. The budget deficit remains virtually unchanged at about 6 percent of GDP, while the current account deficit gradually rises from a surplus of 0.2 percent in FY2011 to almost 4 percent in FY2016. Throughout the projection period, the country's foreign exchange reserves remain precariously low at less than 2 months of imports. In short, it is a scenario where key economic indicators worsen over time, leading to a clearly unviable and unsustainable situation. The IMF's (2012) staff's assessment is summed up as follows:

Pakistan would face sizeable financing gaps even with low projected official reserves ... public debt remains high throughout the medium term, government refinancing needs remain large, and both public and external debts are particularly sensitive to exchange rate depreciation ... [However,] given large fiscal and external financing 
requirements, risks relate mostly to potential liquidity rather than solvency concerns (pp. 13-14, emphasis added).

Table 5: IMF scenarios

\begin{tabular}{lrrrrrr}
\hline \multicolumn{1}{c}{ Indicator } & FY11 & FY12 & FY13 & FY14 & FY15 & FY16 \\
\hline Baseline Scenario & & & & & & \\
GDP growth (\% change) & 2.4 & 3.4 & 3.5 & 3.5 & 3.5 & 3.5 \\
Inflation (\% change) & 13.7 & 12.0 & 12.5 & 13.0 & 13.5 & 14.0 \\
Budget deficit (\% of GDP) & -6.6 & -6.9 & -6.3 & -6.1 & -5.9 & -5.8 \\
Trade deficit & -5.9 & -7.4 & -7.1 & -7.7 & -7.7 & -7.8 \\
Current account (\% of GDP) & 0.2 & -2.0 & -2.0 & -3.0 & -3.3 & -3.7 \\
Gross reserves (months of & 3.8 & 2.9 & 2.3 & 1.6 & 1.6 & 1.7 \\
imports) & & & & & & \\
\hline Reform Scenario & & & & & & \\
GDP growth (\% change) & 2.4 & 3.8 & 4.5 & 5.0 & 5.5 & 5.5 \\
Inflation (\% change) & 13.7 & 12.0 & 11.0 & 10.0 & 9.0 & 8.0 \\
Budget deficit (\% of GDP) & -6.6 & -5.7 & -4.4 & -3.6 & -3.3 & -3.0 \\
Current account (\% of GDP) & 0.2 & -2.1 & -1.7 & -2.5 & -2.6 & -2.8 \\
Forex reserves (months of & 3.8 & 3.0 & 3.0 & 3.0 & 3.0 & 3.0 \\
imports) & & & & & & \\
\hline
\end{tabular}

Source: IMF (2012).

The staff report, however, also contains a "Reform Scenario" (see Table 5). The basic assumptions of this scenario are that the authorities will implement "prudent fiscal and monetary policies and structural reforms" (p. 15). The report states:

Over the medium term, tax policy, energy, business climate, and other structural reforms ... should enable further fiscal consolidation and higher productivity. The scenario assumes much less bank financing of the fiscal deficit and less crowding out of private credit. Together, these policies and reforms would produce higher growth, lower unemployment and inflation, and a more robust reserve cover" (p. 15).

In concrete terms, these measures help to raise GDP growth rate gradually to 5.5 percent while inflation declines to 8 percent. The budget deficit is reduced to 3 percent of GDP and the current account deficit falls 
below 3 percent by the end of the projected period. Because of the reforms, the country's foreign exchange reserves can be maintained at three months of imports.

In the Heterodox Scenario, as noted, output growth and inflation are exogenously specified targets. In contrast to the IMF projections, this scenario envisages GDP growth to rise slowly to 7 percent as inflation comes down to 6 percent over the projection period ${ }^{4}$ (Table 6). This has important implications for the budget and trade deficits. With higher economic growth, government expenditures just need to be contained, not reduced, while a steady improvement in tax collection helps the actual revenues to grow much more rapidly. With public expenditures contained at 20 percent of GDP and revenues steadily rising to 17 percent, the budget deficit is reduced to 3 percent by FY2016. This is the same outcome as that given by the Reform Scenario, except that it is reached through more gradual fiscal adjustment.

With respect to the trade deficit, a comparison can be made only with the Baseline Scenario since the Reform Scenario does not include that information. In the Heterodox Scenario, because of a steady improvement in exports (rising from 14 percent to 17 percent of GDP) and imports held stable at 20.5 percent of GDP, the trade deficit declines to 3.5 percent, as against the Baseline Scenario's projection of nearly 8 percent of GDP. The Reform Scenario does assume an improvement in export performance while the import ratio is held stable, as in our scenario, which suggests that the trade deficit is projected to be in the vicinity of about 5 percent by FY2016.

Domestic investment and savings rates are critically important for economic growth. Again, only the IMF's Baseline Scenario offers projections for the two. In the first scenario, the projections are, as in other respects, highly pessimistic: Gross capital formation remains depressed at about 13.5 percent of GDP while gross savings, derived as a residual, amount to no more than 10 percent by the end of the projection period (IMF, 2012, Table 6) This is a particularly depressing view because the investment rate was some five percentage points higher even during the 2008 crisis. No information is available in the staff report as to the assumptions concerning investment in the Reform Scenario.

In the Heterodox Scenario, on the other hand, GDP growth is held to depend critically on investment, though it is recognized that it would

\footnotetext{
${ }^{4}$ It is to be noted that money income rises at the same rate as in the IMF's Reform Scenario.
} 
not happen quickly. In our projections, gross capital formation is projected to rise to nearly 20 percent by FY2016 - about the level achieved during the high-growth period of 2004-07 (see Table 6). If government investment remains at levels projected by the IMF (i.e., under 4 percent), the burden of the increase in investment will have to be borne by the private sector. Thus, in the Heterodox Scenario, nongovernment investment (i.e., including state enterprises) is projected to rise from about 10 percent in the base period (FY2012) to 16 percent in FY2016. This is not an unrealistic expectation; nongovernment investment in FY2009 was about 15 percent, and in the years just before the crisis, even higher. The current low rates are a result of the depressed economic conditions and need not be accepted as something permanent.

Table 6: Heterodox Scenario

\begin{tabular}{lrrrrrr}
\hline Indicator & FY11 & FY12 & FY13 & FY14 & FY15 & FY16 \\
\hline GDP growth (\% change) & 2.4 & 3.4 & 4.0 & 5.0 & 6.0 & 7.0 \\
Gross capital formation & 13.4 & 13.4 & 14.2 & 15.8 & 18.0 & 19.7 \\
Government & 2.6 & 3.1 & 3.2 & 3.3 & 3.5 & 3.7 \\
Other & 10.8 & 10.3 & 11.0 & 12.5 & 14.5 & 16.0 \\
Domestic savings & 6.5 & 6.5 & 8.1 & 9.7 & 12.9 & 15.6 \\
Govt. revenue & 12.8 & 12.8 & 14.0 & 15.0 & 16.0 & 17.0 \\
Govt. expenditures & 19.1 & 19.5 & 20.0 & 20.0 & 20.0 & 20.0 \\
Budget deficit & -6.4 & -6.8 & -6.0 & -5.0 & -4.0 & -3.0 \\
Exports including NFS & 14.8 & 12.9 & 14.0 & 15.0 & 16.0 & 17.0 \\
Imports including NFS & 20.5 & 20.3 & 20.5 & 20.5 & 20.5 & 20.5 \\
Trade deficit & -5.9 & -7.4 & -6.5 & -5.5 & -4.5 & -3.5 \\
Forex reserves (months of & 4.2 & 3.6 & 3.0 & 3.0 & 3.0 & 3.0 \\
imports) & & & & & & \\
Change in money supply (\%) & 15.9 & 10.7 & 11.8 & 11.3 & 10.8 & 11.0 \\
Velocity of circulation (V) & 2.7 & 2.8 & 2.9 & 3.0 & 3.0 & 3.1 \\
Inflation (\%) & 13.7 & 12.0 & 11.0 & 9.0 & 7.0 & 6.0 \\
\hline
\end{tabular}

Note: Unless otherwise indicated, the data is given as a percentage of GDP. See the Appendix for data details.

As is common to similar exercises, gross domestic savings are derived as a residual. The consequence of rising investment rates and falling foreign transfers (as a proportion of GDP) is that domestic savings must rise very substantially-from 6.5 percent in FY2012 to over 15 percent in FY2016. Given Pakistan's poor past record, this would appear to be a daunting task and could very well frustrate the goal of higher economic growth. However, the projected rate of 15 percent is still considerably 
lower than the rates achieved in the more rapidly growing economies but broadly similar to Pakistan in terms of per capita income.

There are two reasons why Pakistan's savings performance could improve dramatically with rising investment and accelerating economic growth. First, a high proportion of private investment is usually selffinanced in developing economies. If there are investment opportunities and there is eagerness to exploit them, then investors are seldom deterred for lack of financing; they mobilize their own savings. Second, private consumption tends to lag behind rises in individual incomes for precautionary reasons (individuals may not believe that the increase in income is permanent) and because consumption habits change slowly. That these factors can be important under rapid growth is supported by the experience of other countries. India's savings rate, which was also once quite low, rose from 23 percent in 2000 to 34 percent in 2010, while that of Indonesia rose from 27 to 33 percent over the same period (see Table 2 in Akyüz, 2012). Pakistan's savings rate, too, could therefore rise under conditions of higher investment and higher economic growth.

\section{Noninflationary Triggers of Economic Growth}

There are several reasons why Pakistan's economic growth must accelerate. The rapidly rising population and labor supply is obviously the most important reason: Adequate economic growth would permit an increase in living standards while keeping unemployment in check. At the same time, social expenditures - on education, health, and social welfaremust, as a minimum, keep up with the population increase, which is not possible without commensurate income growth. Then, there is the imperative of keeping the country's external debt burden manageable, which too requires a suitable rise in export earnings as well as national income. Last but not least, Pakistan's economy should seek to keep up with its neighbors because low growth implies lower productivity growth, which, over time, means a loss of competitiveness in markets where its neighbors compete.

Given these considerations, Pakistan should aim to reach a growth rate of at least 7 percent within the next few years and then be expected to sustain it over a period of time. This was the pace of growth that the country reached during 2004-07, and is about the same as others' in the region. India's growth rate was higher, but it seems now to be slowing down. Achieving higher growth would require first that Pakistan's economy move toward its existing potential and then embark on 
sustainable longer-term growth. What measures and policies would be required to achieve that goal demands extensive discussion among Pakistan's policymakers in order to arrive at a suitable strategy. This section addresses three areas that are likely to be foremost in any discussion on the country's future growth: (i) overcoming the energy crisis, (ii) stimulating private investment, and (iii) improving Pakistan's competitiveness in the world market.

\subsection{The Energy Crisis}

There are various factors that are responsible for Pakistan's belowpar economic performance-the aftermath of the 2008 crisis, political turbulence, natural and manmade disasters, etc.- - but the persisting energy crisis is probably the single most important reason for the underutilization of the existing productive capacity. No firm estimates are available on the cost of power cuts to industry, but there have been press reports of serious losses in certain key industries, notably, textiles and cement. As a rough guess, industrial output could improve by some 10-15 per cent if energy supply-electricity, gas, and other fuels—became adequate.

The problem of power shortage has festered now for several years; despite government promises and pronouncements, there are few signs that the situation will improve in the near future. The energy crisis has become one of the most hotly debated issues in public forums and in the media, but no consensus has emerged as to its causes or solution. Apart from routine pronouncements and handwringing, the government has shown neither the political will nor seriousness to tackle the problem. ${ }^{5}$ Pakistan's energy problem is complex and highly politicized, involving contractual obligations with the power suppliers, system inefficiencies, pilferage, and the so-called circular-debt problem. Nevertheless, it obviously has to be overcome if there is to be a turnaround in the country's economic fortunes.

\subsection{Private Investment}

The Heterodox Scenario discussed in the last section is based on the assumption that fiscal and monetary policies will remain prudent.

\footnotetext{
${ }^{5}$ One account of the bizarre nature of discussions on the energy crisis was recently reported in a newspaper. At an official meeting on the energy crisis, one planning official declared, "Energy crisis is because of an intellectual crisis in the country [sic]." When asked to reconsider his position, he taunted the audience by asking, "Is there anybody in the conference hall who can speak proper English?” (Asif, 2012).
} 
Although overall public expenditures will have to be contained, more rapid growth will depend on adequate public investment in infrastructure, education, and health. This will entail a reversal of the past policy of neglect if the deterioration in these critically important sectors is to be arrested. Nevertheless, the upshot is that private investment-rather than public expenditures-will drive accelerated growth and will have to rise sharply over the coming years. In the Heterodox Scenario, nongovernment investment (including public enterprises) is projected to rise from the current level of 10 percent of GDP to 17 percent in FY2016. The question that then arises is, how might this happen?

Private investment in Pakistan, even during the boom periods, has been far from remarkable. It rose somewhat during the Musharraf era, following the loosening of monetary policy in 2003/04, but was channeled mostly to the banking sector, telecommunications, and real estate.

Studies that have addressed the issue of private investment (see Asian Development Bank, 2008) identify the same weaknesses as found in other countries, i.e., the macroeconomic situation, governance, political instability, property rights, labor market rigidities, energy shortages, and infrastructure deficit. While these factors may have held back some investors, they do not quite explain Pakistan's exceptionally low level of private investment as compared to other countries. In terms of the International Finance Corporation and World Bank's Doing Business index, Pakistan has remained ahead of India and Bangladesh for the past several years in many respects. The latest index for the South Asia region (June 2011), ranks Pakistan at 3 with respect to "ease of doing business," 6 with respect to "starting business," and 2 with respect to "getting credit." India's rankings are 6,8, and 1, respectively; while Bangladesh's rankings for the same are 5, 5, and 4 (see Table 7). In terms of "enforcing contract" and "resolving insolvency," Pakistan is, again, well ahead of India and Bangladesh. Overall, Sri Lanka comes close to the top in the region. 
Table 7: Doing Business index economy rankings for South Asia

\begin{tabular}{lcccc}
\hline Index & Bangladesh & India & Pakistan & Sri Lanka \\
\hline Ease of doing business & 5 & 6 & 3 & 2 \\
Starting a business & 5 & 8 & 6 & 2 \\
Dealing with construction permits & 2 & 8 & 3 & 4 \\
Getting electricity & 8 & 2 & 7 & 1 \\
Registering property & 8 & 3 & 4 & 6 \\
Getting credit & 4 & 1 & 2 & 4 \\
Protecting investors & 1 & 3 & 2 & 3 \\
Paying taxes & 5 & 6 & 7 & 8 \\
Trading across borders & 4 & 3 & 2 & 1 \\
Enforcing contracts & 7 & 8 & 5 & 3 \\
Resolving insolvency & 5 & 7 & 3 & 2 \\
\hline
\end{tabular}

Source: International Finance Corporation and World Bank (2011, June).

In brief, the investment environment in Pakistan appears to be similar to, if not better than, countries where private investment has been much more active. Sayeed and Memon (2007) in fact argue that conventional tools used in "investment climate" literature-notably institutions, governance, etc.-are not satisfactory in explaining Pakistan's "low investment puzzle." What seems to matter to private investors is the stability and credibility of economic policy rather than its specifics, such as the levels of tax rates or interest rates (Pindyck \& Solimano, 1993). It is also the case that private investment decisions are greatly influenced by other investors' actions and behavior. Thus, economic growth-if it could somehow be kick-started-itself could generate a virtuous circle of investment and growth. Conversely, investor timidity and low economic activity feed on each other, which is probably at the root of Pakistan's stagflationary situation.

The conclusion from the discussion above is that, while there is no simple explanation for private investment, expectations concerning the country's future economic performance and the clarity and credibility of policy could be decisive. Thus, if it became established that policymakers were serious and agreed on a strategy of accelerated growth, it might be possible to break into the investment-growth virtuous cycle. At the same time, there is no question that some of the private sector's longstanding concerns-notably power supply, infrastructure bottlenecks, insecurity, etc.-would also have to be addressed. 


\subsection{International Competitiveness}

Pakistan has had bursts of rapid economic growth but they have all sputtered, almost invariably because of the emergence of untenably large trade deficits. Balance of payments viability is, therefore, a sine qua non for the durability and sustainability of growth, which means action on imports as well as exports.

Import growth is now hard to control by means of conventional trade policy because of the prevailing World Trade Organization (WTO) rules. A country might invoke the WTO's balance of payments clause, which allows temporary trade measures when a country is faced with serious balance of payments difficulties, but the IMF must agree. Another possibility is to apply selectively high domestic taxes on luxuries and other nonessential imports, which could curb imports while yielding additional public revenue. However, given the government's weak revenue-raising capabilities, this too may not be practical.

The critical determinant of balance of payments viability will, in fact, be export growth. Under the Heterodox Scenario, exports are projected to rise from the current level of about 14 percent to 17 percent of GDP, which represents an annual increase of about 16 percent or more than doubling in value during the projection period. Achieving this goal will require a coordinated, resolute effort on the government's part as well as the private sector's to seek out export opportunities and improve Pakistan's standing in the world market in terms of the quality and cost of its exports.

The exchange rate is commonly regarded as the key determinant of the country's competitiveness and a policy instrument of choice for improving the trade balance (see, for example, Pakistan, Planning Commission, 2008). But the exchange rate is unlikely to do the trick in Pakistan's case. For one thing, the rupee's real effective exchange rate has been, according to the IMF's own assessment, "relatively stable since the end of the 1990s" (2012, p. 12) and minor appreciations were short-lived. For another, the IMF now classifies Pakistan's exchange rate regime as "floating," which means that the currency is no longer actively managed. With a virtually open capital account, the rupee value is likely to be driven more by foreign financial flows than by the state of the country's trade balance (Haque, 2011). In any case, exchange rate depreciation works to improve the trade balance only through a reduction in real wages, which gives at best a temporary cost advantage as wages cannot be kept depressed for long. 
A durable improvement in competitiveness depends essentially on productivity growth, which is the real driver of production costs and living standards (Haque, 1995). A country's competitive advantage lies in ensuring that its productivity growth at least matches the growth in competitor countries. However, in a world where products and processes are constantly undergoing technological change, this is not easy nor does it automatically follow from competition. Investment in new plants and equipment can contribute to productivity growth through embodied technology. Countries with high investment rates-as is the case in fastgrowing economies-are, therefore, better able to adopt newer production processes and produce new products. But, as the experience of centrally planned economies shows, that is not always enough.

In order to stay competitive, productivity improvement has to become part of routine economic activity. In effect, a culture of creativitya continuous search for improvements in products and processes-has to become pervasive, not just in the modern industry but also in traditional sectors $^{6}$ (Haque, 1995). This is what drove the Industrial Revolution in Europe and brought about the technological transformation in East Asia that underpinned the region's phenomenal growth over the past several decades. While the government can create conditions where the search for technological improvements becomes appealing and profitable-e.g., by enforcing intellectual property rights, setting standards, and supporting research and development (R\&D) and quality control, etc.- the decisions on how and what to produce, on adopting new technologies, undertaking market research and $\mathrm{R} \& \mathrm{D}$, and, not least, on training the workforce are ultimately made at the firm level. Competition promotes the search for technological improvements, but its translation into investment and other actions depends on firms taking a longer-term view, rather than searching for a quick return. For this to materialize, a stable economic and political environment is important because instability breeds uncertainty, which in turn tends to make firms shortsighted in their investment decisions.

Bringing about the changes necessary for Pakistan's competitiveness might appear a tall order, but other similar countries have

\footnotetext{
${ }^{6}$ Traditional sectors generally constitute a higher proportion of domestic output, which means productivity improvements there have a greater weight in overall growth. Specifically, in Pakistan, productivity improvements in agriculture would have a far greater impact on overall productivity growth than improvements in modern industry.
} 
been successful and are today ranked as top economic performers. ${ }^{7}$ In fact, there is considerable creativity in Pakistan, judging by the innovativeness of firms and individuals in different industries, notably in textiles, software, and surgical goods. There is also a display of brilliance by young Pakistani artists and designers within as well as outside the country. But these are still episodic achievements, and not quite enough to lift a nation of 180 million to join the club of the Asian giants (Green \& Sender, 2012).

\section{Concluding Observations}

Under the Heterodox Scenario, Pakistan's economy is projected to achieve higher growth with economic stability, provided public expenditures and imports are contained at permissible levels while public revenues and export earnings rise to keep the macroeconomy stable. This article has identified three triggers of noninflationary economic growth. In the immediate term, a resolution of the energy crisis-arguably the highest priority-is critical to the expansion of output and enabling domestic industry to reach its potential. The pace and sustainability of growth in the longer term, on the other hand, will depend on private investment and productivity growth, which underpins the country's competitiveness in the world market. Although Pakistan's past record is not reassuring with respect to any of these areas, the situation can and should be improved.

Although this article is not intended to provide a strategy for how accelerated growth might actually materialize, we offer below a few ideas on how to proceed. Only the national government can develop a strategy for growth because it can marshal the required technical expertise and other resources to draw up a proper, realistic blueprint and action plan, and then mobilize the critically important political support for its implementation. Because of its expected role, the private sector's commitment to national development is vital, and would require its close involvement in the strategy's development.

The capacity of the government, or more broadly, the public sector, is severely limited in terms of financial resources and administrative capability,

\footnotetext{
7 The World Bank (1991) notes: "Forty-three years ago an influential government report in an important developing country observed that labor today shunned hard, productive jobs and sought easy, merchant-like work. The report showed that workers' productivity had fallen, wages were too high, and enterprises were inefficient and heavily subsidized. The country ... was overpopulated and becoming more so. This would be the last opportunity, concluded the prime minister in July 1947 , to discover whether his country would be able to stand on its own two feet or become a permanent burden for the rest of the world. That country was Japan." (pp. 13-14).
} 
but it still bears the responsibility for getting its policies and programs implemented, ensuring an equitable distribution of the costs and benefits of growth, and providing adequate resources to crucial health, education, and social welfare activities. It is a mistake- even dangerous - to dismiss the public sector as inherently inefficient, as has become fashionable in some policy circles. As noted earlier, in terms of the usual indicators, Pakistan's national economic management is actually no worse than that of some other fast-growing economies, though this is no reason for complacency.

Accelerated growth can be viewed as a virtuous circle, where rising investment and growth feed on each other. But the question that remains is how to jump-start the process. Since the economy is not demandconstrained, the usual stimuli of growth-enlarged public expenditures and loose monetary policy-would be unnecessary. Nevertheless, the fact that, under the Heterodox Scenario, public expenditures rise in step with income growth could be expected to reinforce the growth momentum.

Some sort of spur, however, is still needed to overcome investor timidity and to encourage the private sector to start investing more actively. We believe that resolving the energy crisis could alone make a considerable difference to the investment climate. Improving the currently loss-making public enterprises could also help, because that would not only reduce the drain on public finances but also stimulate economic activity through better provision of critically important infrastructure, notably in surface transportation (Pakistan Railways) and air travel (PIA). Whether the solution lies in privatizing these entities-as often recommended-must be a decision based on a careful weighing of the costs and benefits of different alternatives. There is no certainty that the private sector would run them any better, as has become evident from the power sector's problems and recent incidents concerning safety in the airline industry. There is also a real risk of "asset stripping" in the case of privatization, which would be a serious national loss. As an alternative to privatization, public sector-business partnerships could be exploredalong the lines of the recently launched Pak Business Express-which could also provide the beneficial fillip to overall investment.

Pakistan's continuing difficulties on different fronts have created a general mood of despair and despondency. But its problems are largely homegrown and, in certain respects, quite recent. This article has sought to demonstrate the feasibility of an accelerated growth strategy, which could be regarded as a response to the general lament over Pakistan's poor economic performance. A general rise in living standards and reduction in 
unemployment resulting from higher growth could conceivably help to lessen the disharmony, insecurity, and pessimism that have come to permeate Pakistani life. This has happened in other countries, notably, Indonesia, Malaysia, and Mauritius during the 1960s. "Nothing succeeds like success" would be a useful dictum to get Pakistan moving. 


\section{References}

Akyüz, Y. (2012). The staggering rise of the south (Research Paper No. 44). Geneva, Switzerland: South Centre.

Amjad, R, Din, M., \& Qayyum, A. (2011). Pakistan: Breaking out of stagflation into sustained growth [Special edition]. Lahore Journal of Economics, 16, 13-30.

Asian Development Bank. (2008). Private sector assessment: Pakistan. Manila, Philippines: Author.

Asif, M. (2012, April 20). No answers to energy crisis. Dawn.

Bruno, M., \& Easterly, W. (1996). Inflation and growth: In search of a stable relationship. Federal Reserve Bank of Saint Louis Review, 78, 139-146.

Dornbusch, R., \& Fischer, S. (1993). Moderate inflation. World Bank Economic Review, 7(1), 44.

Espinoza, R., Leon, H., \& Prasad, A. (2010). Estimating the inflation-growth nexus: A smooth transition model (Working Paper WP/10/76). Washington, DC: International Monetary Fund.

Fischer, S. (1993). The role of macroeconomic factors in growth. Journal of Money Economics, 32(3), 485-512.

Green, M., \& Sender, H. (2012, March 1). Pakistan: In the shadow of giants. The Financial Times.

Haque, I. (1995). Trade, technology, and international competitiveness. Washington, DC: World Bank, Economic Development Institute.

Haque, I. (2010). Pakistan: Causes and management of the 2008 economic crisis (Global Economy Series 22, Financial Crisis and Asian Developing Countries). Penang, Malaysia: Third World Network.

Haque, I. (2011). The capital account and Pakistani rupee convertibility: Macroeconomic policy challenges [Special edition]. Lahore Journal of Economics, 16, 95-121. 
International Finance Corporation and World Bank. (2011, June). Economy rankings. Retrieved from http:/ /www.doingbusiness.org/rankings/

International Monetary Fund. (2009). Pakistan: 2009 Article IV consultation (Country Report No. 09/123). Washington, DC: Author.

International Monetary Fund. (2012). Pakistan: 2011 Article IV consultation and proposal for post-program monitoring (Country Report No. 12/35). Washington, DC: Author.

Mubarik, Y. A. (2005). Inflation and growth: An estimate of the threshold level of inflation in Pakistan. State Bank of Pakistan Research Bulletin, 1, 35-44.

Pakistan, Planning Commission. (2008). Economic stabilisation with a human face: Report of the panel of economists. Islamabad, Pakistan: Author.

Pakistan, Planning Commission. (2011). Pakistan: Framework for economic growth. Islamabad, Pakistan: Author.

Pindyck, R. S., \& Solimano, A. (1993). Economic instability and aggregate investment (Policy Research Working Paper No. 1148). Washington, DC: World Bank.

Polak, J. (1997). The IMF monetary model at forty (Working Paper No. WP/97/49). Washington, DC: International Monetary Fund.

Sayeed, A., \& Memon, R. (2007). Beyond the investment climate: Understanding the investment conundrum in Pakistan. Falmer, UK: Institute of Development Studies.

World Bank. (1991). World development report 1991: The challenge of development. Washington, DC: Author.

World Bank. (2012). World development indicators. Washington, DC: Author. 


\section{Appendix: Heterodox Scenario}

Table A1: Heterodox scenario, part I: Balance of payments

\begin{tabular}{lrrrrrrrr} 
& & & & & & \multicolumn{3}{c}{ (USD billion) } \\
\hline & FY09 & FY10 & FY11 & $\begin{array}{c}\text { FY12 } \\
\text { Estimate }\end{array}$ & FY13 & FY14 & FY15 & FY16 \\
& & & & & Projections \\
\hline GDP (mp) & 161.8 & 176.9 & 210.6 & 233.5 & 268.5 & 306.1 & 345.9 & 390.9 \\
Exports incl. nfs & 23.2 & 24.9 & 31.1 & 30.0 & 37.6 & 45.9 & 55.3 & 66.5 \\
Imports incl. nfs & 39.2 & 38.1 & 43.5 & 47.3 & 55.0 & 62.8 & 70.9 & 80.1 \\
Trade balance & -16.0 & -13.2 & -12.4 & -17.3 & -17.5 & -16.8 & -15.6 & -13.7 \\
Net foreign reserves (end period) & 9.1 & 13.2 & 15.4 & 14.3 & 13.8 & 15.7 & 17.7 & 20.0 \\
Net foreign transfers (required) & 16.6 & 17.3 & 14.6 & 16.2 & 16.9 & 18.8 & 17.6 & 16.0 \\
\hline As a percentage of GDP & & & & & & & & \\
Exports incl. nfs & 14.4 & 14.1 & 14.8 & 12.9 & 14.0 & 15.0 & 16.0 & 17.0 \\
Imports incl. nfs & 24.2 & 21.6 & 20.5 & 20.3 & 20.5 & 20.5 & 20.5 & 20.5 \\
Trade balance & -9.9 & -7.5 & -5.9 & -7.4 & -6.5 & -5.5 & -4.5 & -3.5 \\
Net foreign reserves \% of imports & 23.2 & 34.5 & 35.4 & 30.2 & 25.0 & 25.0 & 25.0 & 25.0 \\
Foreign reserves (months) & 2.8 & 4.1 & 4.2 & 3.6 & 3.0 & 3.0 & 3.0 & 3.0 \\
\hline
\end{tabular}

* IMF (2012) consultations document, Tables 6 and 7. The IMF gross official reserves exclude foreign currency deposits at the SBP.

Assumptions: GDP growth during FY2013-16 is 4, 5, 6, and 7 percent, respectively; while inflation is $11,9,7$, and 6 percent, respectively. Imports are a constant proportion (20.5 percent) of GDP; foreign exchange reserves are expected to decline to 3 months of imports in FY2013 and stay at that level for the projection period. Exports rise steadily to 17 percent of GDP from a level of 14 percent at the start of the period. The exchange rate is held constant at PKR 90 to USD 1.

\section{Monetary data}

(PKR billion)

\begin{tabular}{lrrrrrrrr}
\hline & FY09 & FY10 & FY11 & FY12 & FY13 & FY14 & FY15 & FY16 \\
\hline Broad money & 5,137 & 5,777 & 6,695 & 7,409 & 8,284 & 9,223 & 10,217 & 11,340 \\
Velocity of circulation (V) & 2.48 & 2.57 & 2.70 & 2.81 & 2.89 & 2.96 & 3.02 & 3.08 \\
Change in money supply & 433 & 640 & 918 & 714 & 875 & 939 & 994 & 1,123 \\
Net foreign reserves* & 752 & 856 & 1,137 & 1,286 & 1,239 & 1,412 & 1,596 & 1,803 \\
Total domestic claims & 4,385 & 4,921 & 5,558 & 6,123 & 7,045 & 7,811 & 8,621 & 9,537 \\
Change in reserves & -100 & 104 & 281 & 149 & -48 & 173 & 184 & 207 \\
Net domestic credit & 533 & 536 & 637 & 565 & 923 & 766 & 810 & 916 \\
\hline
\end{tabular}

* Foreign reserves converted at PKR 90/USD for the projection period. 
Table A2: Heterodox scenario, part II: Fiscal data

(PKR billion)

\begin{tabular}{lrrrrrrrr}
\hline & FY09 & FY10 & FY11 & $\begin{array}{c}\text { FY12* } \\
\text { Estimate }\end{array}$ & FY13 & $\begin{array}{c}\text { FY14 } \\
\text { Projections }\end{array}$ & FY15 & FY16 \\
\hline GDP (mp) & & & & & \\
General govt. revenue & 12,724 & 14,837 & 18,062 & 20,844 & 23,971 & 27,326 & 30,879 & 34,893 \\
General govt. expenditures & 2,531 & 3,006 & 3,454 & 4,070 & 4,794 & 5,465 & 6,176 & 6,979 \\
Overall budget deficit & -659 & -876 & $-1,148$ & $-1,407$ & $-1,438$ & $-1,366$ & $-1,235$ & $-1,047$ \\
\hline As a percentage of GDP & & & & & & & & \\
Govt. revenue & 14.7 & 14.4 & 12.8 & 12.8 & 14.0 & 15.0 & 16.0 & 17.0 \\
Govt. expenditures & 19.9 & 20.3 & 19.1 & 19.5 & 20.0 & 20.0 & 20.0 & 20.0 \\
Overall budget deficit & -5.2 & -5.9 & -6.4 & -6.8 & -6.0 & -5.0 & -4.0 & -3.0 \\
\hline
\end{tabular}

* IMF baseline.

\section{Savings/investment balance}

(PKR billion)

\begin{tabular}{lrrrrrrrr}
\hline \multicolumn{1}{c}{ Percentage of GDP } & FY09 & FY10 & FY11 & FY12 $^{*}$ & FY13 & FY14 & FY15 & FY16 \\
\hline Gross capital formation* & 18.2 & 15.4 & 13.4 & 13.4 & 14.2 & 15.8 & 18.0 & 19.7 \\
Government & 3.1 & 3.5 & 2.6 & 3.1 & 3.2 & 3.3 & 3.5 & 3.7 \\
Other (incl. public enterprises) & 15.1 & 11.9 & 10.8 & 10.3 & 11.0 & 12.5 & 14.5 & 16.0 \\
Net foreign transfers & 10.3 & 9.8 & 6.9 & 6.9 & 6.3 & 6.1 & 5.1 & 4.1 \\
Gross domestic savings (residual) & 7.9 & 5.6 & 6.5 & 6.5 & 8.1 & 9.7 & 12.9 & 15.6 \\
GDP growth rate & & 16.6 & 21.7 & 15.4 & 15.0 & 14.0 & 13.0 & 13.0 \\
\hline
\end{tabular}

* IMF (2012), Table 6 for FY2009-12; for government investment, entire data from IMF. 